\title{
Vibrio anguillarum from an Endemic Disease of Ayu in Lake Hamana
}

\author{
Kiyokuni MURoga and Syuzo EguSA* \\ (Received May 2, 1967)
}

In Lake Hamana, a salt lake located in the middle part of the southern coast of Japan, the young of Ayu, Plecoglossus altivelis, less than $1 \mathrm{~g}$ in body weight are caught in great numbers in early spring. Fish caught are held for a short time in ponds or large net-cages set up in the lake and then shipped to various Ayu farms or rivers for stocking. During this holding they are often attacked by an acute, fatal disease, which is thought to exist in the lake itself. The characteristic symptom of the disease is the appearance of a cloudy area, occasionally accompanied by hemorrhage, in the body musculature. The lesion is visible from the exterior, because the body is semitranslucent. Generally fish die before the lesions become more extensive and destructive.

In April, 1965, the present authors had an opportunity to examine some fishes in the initial stage of the disease and a vibrio was isolated in pure culture from their muscle lesions. Subsequently it was shown by inoculation experiments that the organism was pathogenic not only for Ayu but also for eels, producing "red disease" in the latter. The same bacterium was isolated from internal organs as well as muscle lesions of diseased specimens in March, 1966 and 1967 also and a further study of its characteristics and pathogenicity was undertaken.

\section{Experimental Methods and Results}

Description of isolates: Six cultures isolated in 1965 and 1966 from muscle lesions or internal organs of different diseased specimens** were examined and found morphologically and physiologically identical. The organism from 24-hr nutrient broth cultures*** was gram-negative, slightly curved short $\operatorname{rod}(1 \sim 2 \times 0.5 \mu)$. It was actively motile by a single polar flagellum, non-sporing and non-capsulate. On nutrient agar plate colonies were circular with an entire edge, convex, moist, glistling and greyish yellow in color. On BTB teepole agar growth was good. The growth was bright yellow in color. On WA agar minute colonies appeared only when cells were abundantly streaked. There was no growth on SS agar or MacConkey agar. Bio-

* Department of Fisheries, Faculty of Agriculture, the University of Tokyo, Tokyo Japan. (室賀清耕・江草周三：菒京大学费学部).

** The temperature and chlorinity of water of ponds from which specimens of fishes were taken ranged $10 \sim 14^{\circ} \mathrm{C}$ and $7 \sim 8 \%$, respectively, at the time of collection.

*** Unless otherwise stated, all the media used for various purposes in this study contained $3 \%$ $\mathrm{NaCl}$ and cultures were all incubated at $28^{\circ} \mathrm{C}$. 
Table 1. Biochemical characteristics of Vibrio anguillarum isolated from diseased young Ayu.

\begin{tabular}{|c|c|c|c|}
\hline Test & Result & Test & Result \\
\hline Gas from carbohydrates & - & Acid from: & \\
\hline Hugh \& Leifson test & Ferment & Glucose & + \\
\hline Cytochrome oxydase & + & Arabinose & $3 / 6 *$ \\
\hline Catalase & + & Xylose & - \\
\hline $\mathrm{H}_{2} \mathrm{~S}$ production & - & Fructose & + \\
\hline Indole production & + & Mannose & + \\
\hline Methyl-red test & - & Galactose & + \\
\hline Voges-Proskauer test & + & Rhamnose & $2 / 6$ \\
\hline Liquefaction of gelatin & + & Mannitol & + \\
\hline 2,3-butanediol production & + & Inositol & $5 / 6$ \\
\hline Chorela-red test & - & Sucrose & + \\
\hline Starch hydrolysis & + & Maltose & - \\
\hline Utilization of: & & Raffinose & - \\
\hline$d$-tartaric & + & Lactose & - \\
\hline Malonic & + & Cellobiose & $5 / 6$ \\
\hline Citric & + & Dextrin & + \\
\hline Nitrate reduction & + & Glycogen & $3 / 6$ \\
\hline Urease & - & Starch & + \\
\hline Chitin decomposition & Weakly positive & Glycerin & $2 / 6$ \\
\hline
\end{tabular}

* Fractional figures: number of strains positive/number tested.
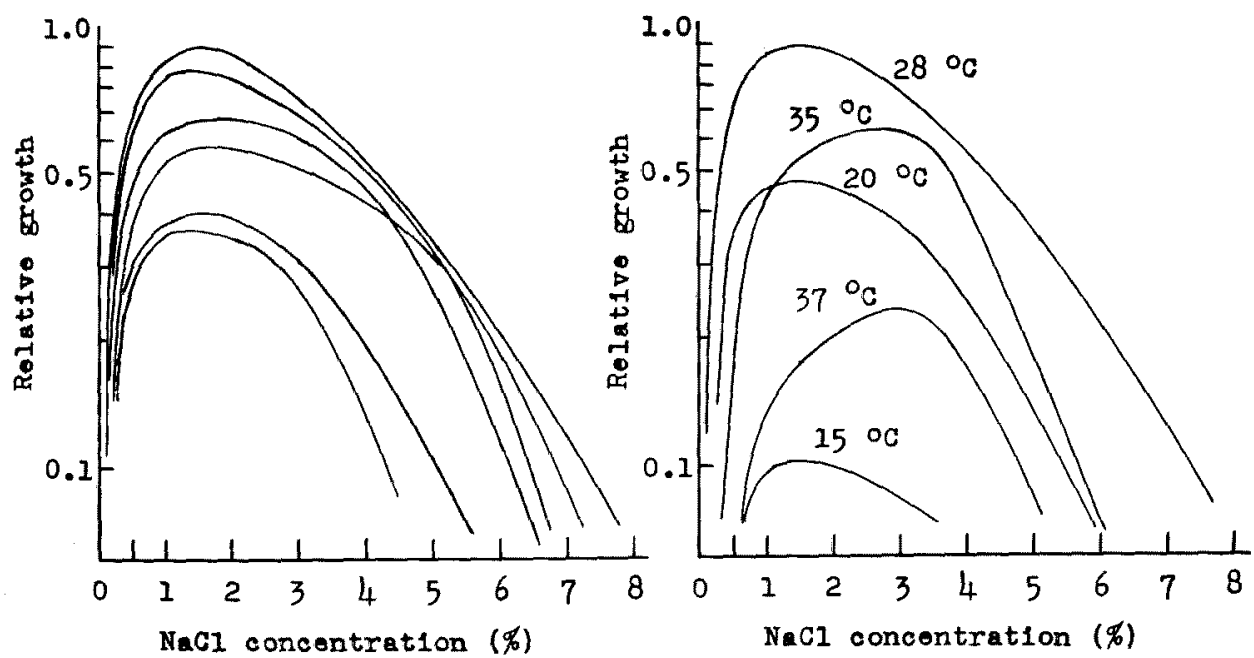

Fig. 1. Effects of $\mathrm{NaCl}$ concentration and temperature on the growth of Vibrio anguillarum isolated from diseased young Ayu. Left: experiments on the 6 strains including strain $\mathrm{PB}-1$, at $28^{\circ} \mathrm{C}$. Right: experiments on strain $\mathrm{PB}-1$. 
chemical characteristics of the organism was given in Table 1.

The temperature, $\mathrm{pH}$ and $\mathrm{NaCl}$ requirements for growth of the 6 strains were studied. The basal medium used was Difco's nutrient broth, unless otherwise stated. They were incubated for 5 to 6 hours on a shaking apparatus and the relative growth was determined photometrically.

Good growth occurred over a rather wide $\mathrm{NaCl}$ range from 0.5 to $4.0 \%$ in every strain, the optimum range being 1 to $2 \%$ at $28^{\circ} \mathrm{C}$ (Fig. 1). All the strains grew well in stagnant pepton water media containing $7 \% \mathrm{NaCl}$ at $28^{\circ} \mathrm{C}$, but in media with $10 \%$ $\mathrm{NaCl}$ half of them failed to grow, though the other half grew faintly. A $0.07 \%$ concentration allowed good growth, and $0 \%$ negligible growth. The optimum temperature was considered to be near $28^{\circ} \mathrm{C}$ (Fig. 1). In stagnant broth media with $3 \%$ $\mathrm{NaCl}$ no growth occurred at $38^{\circ} \mathrm{C}$ and it was faint and slow at $10^{\circ} \mathrm{C}$. The $\mathrm{pH}$ range for growth was 6 to 10 with the optimum between 7 and 8 .

Drug sensitivity in vitro of the strains was tested using Eiken Sensitivity discs. They were all highly sensitive to chloramphenicol, tetracycline, colistine and novobiocin, relatively weakly sensitive to oleandmycin and resistant to penicillin. It was also sensitive to the vibriostatic agent $0 / 129$.

Pathogenicity: Attempts were made to infect Ayu and eels by intramuscular injection with the organism. Most of the fishes used were taken from freshwater ponds. Fishes which had been kept in sea-water $\left(\mathrm{Cl}^{\prime}=17 \sim 18 \%\right)$ for over 3 weeks were also challenged. In preparation for inocula cells were scraped from the surface of nutrient agar plates after $24-\mathrm{hr}$ incubation at $28^{\circ} \mathrm{C}$ and suspended in sterile saline in various concentrations.

A dose of $1 \mathrm{mg}$ of bacteria per $100 \mathrm{~g}$ fish body weight killed samples of Ayu $(7 \sim 12 \mathrm{~g})$ in 30 hours $\left(15 \sim 17^{\circ} \mathrm{C}\right)$ and eels $(60 \sim 100 \mathrm{~g})$ within 2 days $\left(20 \sim 25^{\circ} \mathrm{C}\right)$ and a dose of $0.1 \mathrm{mg}$ killed both Ayu $\left(13 \sim 14^{\circ} \mathrm{C}\right)$ and eels $\left(20 \sim 25^{\circ} \mathrm{C}\right)$ within 3 days. Some of the eels received doses of $0.01 \sim 0.05 \mathrm{mg}$ died in 3 to 5 days. There was no marked difference in pathogenicity among the strains. In view of its halophilic nature it is important to note that the organism is pathogenic for freshwater Ayu and eels as well as those acclimated to sea-water (Table 2).

Briefly, pathological features of inoculated fish were as follows: First, the site of inoculation became hemorrhagic, gradually swelled up and finally became necrotic. Usually Ayu died before the tissues of the inoculation site became markedly necrotic and other conspicuous external symptoms appeared. Histological examination of moribund specimens, however, revealed that the intestines ordinarily underwent marked pathological changes and the spleens and kidneys were often affected. On the contrary, in eels many hemorrhagic spots appeared in various parts of the body surface and marked congestion developed in the fins in advanced stages. Occasionally necrotic areas developed in any parts of the body surface. These symptoms coincide with those of red disease ${ }^{1)}$. No definite lesions developed, however, in the internal 
Table 2. Effects of Vibrio anguillarum isolated from diseased young Ayu on freshwater and sea-water-acclimated fish.

\begin{tabular}{|c|c|c|c|c|c|c|}
\hline \multirow[t]{2}{*}{ Fish } & \multirow[t]{2}{*}{$\begin{array}{l}\text { Experimental } \\
\text { conditions }\end{array}$} & \multicolumn{4}{|c|}{$\begin{array}{c}\text { Time to die } \\
\text { (hours in Ayu; days in eels) } \\
\text { Amount of bacterial cells inoculated } \\
\text { (mg in wet weight) per } 100 \mathrm{~g} \\
\text { fish body weight }\end{array}$} & \multirow[t]{2}{*}{$\begin{array}{l}\text { Strain } \\
\text { inoculated }\end{array}$} \\
\hline & & 2.0 & 1.0 & 0.5 & 0.1 & \\
\hline $\begin{aligned} \text { Freshwater } & \text { Ayu } \\
& (5 \sim 12 \mathrm{~g})\end{aligned}$ & $\begin{array}{l}\text { in freshwater } \\
13 \sim 14^{\circ} \mathrm{C}\end{array}$ & 23 & 34 & 42 & 59 & \multirow{2}{*}{$\mathrm{PB}-1$} \\
\hline $\begin{array}{l}\text { Sea-water-acclimated } \\
\text { Ayu } \quad(8 \sim 10 \mathrm{~g})\end{array}$ & $\begin{array}{c}\text { in sea-water }{ }^{*} \\
15 \sim 17^{\circ} \mathrm{C}\end{array}$ & 25 & 30 & 46 & - & \\
\hline $\begin{array}{l}\text { Freshwater eels } \\
\qquad(60 \sim 100 \mathrm{~g})\end{array}$ & $\begin{array}{l}\text { in freshwater } \\
20 \sim 25^{\circ} \mathrm{C}\end{array}$ & 2 & 1 & 3 & 3 & \multirow{2}{*}{$P B-3$} \\
\hline $\begin{array}{l}\text { Sea-water-acclimated } \\
\text { eels } \quad(75 \sim 130 \mathrm{~g})\end{array}$ & $\begin{array}{c}\text { in sea-water* } \\
17 \sim 20^{\circ} \mathrm{C}\end{array}$ & 2 & 2 & - & 3 & \\
\hline
\end{tabular}

* Chlorinity: approximately $18 \%$.

organs. In every case the bacterium inoculated was re-isolated in pure culture from internal organs of infected Ayu and eels.

\section{Discussion}

The organism isolated from diseased specimens of Ayu is a gram-negative, slightly curved short rod and motile by means of a single polar flagellum. It ferments glucose anaerogenically, producing acid but no gas, utilizes tartaric acid and is cytochrome oxydase positive. It can grow in $\mathrm{pH} 9$ and $7 \% \mathrm{NaCl}$. It is sensitive to the vibriostatic agent $0 / 129$. These morphological and biochemical characteristics suggest that the bacterium belongs to the genus Vibrio $^{2,3)}$.

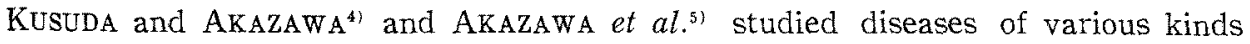
of marine fishes along the coast of Japan and gave full descriptions of the causal organisms, which they classified as members of the genus Vibrio. The members differ, however, from the organism described here in their ability to grow on MacConkey's agar and to kill mice and in their inability to kill freshwater eels.

Among vibrios pathogenic for salt-water fishes $V$. anguillarum is a most known species. In particular the species is known to be responsible for red disease of eels. It was apparent that the present organism was substantially pathogenic for eels, causing typical symptoms of red disease. SMITH ${ }^{6)}$ studied a vibrio isolated from a disease of finnock. In her studies she examined for comparison a strain of $V$. anguillarum from the National Collection of Marine Bacteria at the Torry Research Station. The strain differs from the organism described here only in its inability to ferment starch. NyBELIN ${ }^{7}$ subdivided $V$. anguillarum into two subtypes $A$ and $B$. The present organism fits the descriptions of the type A given by NYBELIN ${ }^{7}$ and WOLTER ${ }^{83}$. 
On the basis of the above, the present authors concluded that this organism should be classified as $V$. anguillarum. Recently LAGARGE and CHAKROUN ${ }^{\text {9) }}$ isolated a vibrio from diseased eels in brakish water and identified it as $V$. anguillarum type B. Their isolate differs definitely, however, from the present organism in its inability to grow in $4.5 \% \mathrm{NaCl}$ and in its pathogenic nature for warm-blooded animals.

The present authors wish to express their thanks to Mr. H. OGAMr of the Hamana Branch Station of the Shizuoka Prefectural Fisheries Experimental Station for the supply of specimens.

\section{Summary}

Characteristics of a vibrio isolated from diseased young of Ayu, Plecoglossus altivelis, in salt-water were determined as well as ability of the bacterium to produce experimental infections. The organism was methyl-red negative, V-P positive, failed to grow on MacConkey's agar and was pathogenic for freshwater Ayu and eels, producing typical symptoms of red disease in the latter, but not for mice. With the characteristics and pathogenicity determined, the bacterium was classified as Vibrio anguillarum.

\section{References}

1) W. SchäPERCLAUS: Zeit. für Fisch., 32, 191 217 (1934).

2) G.H.G. DAvis and W.H. PARK: Jour. Gen. Microbiol., 27, $101 \sim 119$ (1962).

3) R. SAKAZAKI: in "Choen biburio-Vibrio parahaemolyticus" (T. FuJino and H. FuKumI, eds.), p. 422, Isseido, Tokyo, 1963.

4) R. Kusuda and I. Akazawa: Aquiculture, Extra No. 3, $31 \sim 66$ (1963).

5) I. AKAZAWA et al.: Kyotofu Eiseikenkyusho, Kyoto, p. 19 (1966).

6) I.W. SMrTH: Jour. Gen. Microbiol., 24, 247 252 (1961).

7) O. Nybelin: Medd. Umtersökn. Anst. Sötvattensfsk, Stockh., 8, 1 62 (1935).

8) R. Wolter: Zeit. für Fisch,, 9 NF, 763 770 (1961).

9) E. LAGARD and F. Chakroun: Ann. Inst. Pasteur, 108, 135 140 (1955). 